\title{
THEORETICAL FEATURES OF THE CREATIVE SOCIETY
}

\author{
Ramojus REIMERIS \\ Mykolas Romeris University, \\ Faculty of Politics and Management, \\ Institute of Management, \\ Valakupių g. 5, LT-10101, Vilnius, Lithuania \\ E-mail:ramojus@reimeris.com
}

Received 26 April 2015; accepted 27 August 2015

\begin{abstract}
The purpose of this article is twofold. Firstly to analyse and to describe the phenomenon of creative society and to propose the features, distinguishing it from the predecessors - information society and knowledge society. Secondly to reveal the relation of creative society with creative economy and regional specialization. Research is based on the analysis of the relevant literature. The findings reveal that creative society is an extension to information society and knowledge society, but with the different set of main features. Creative society is foundation of the creative economy embedded to the place where it exists. It is organized in non-hierarchical form and opts for the exclusivity, with individual approach to the creation and specific roots in the education. By its nature the creative society is very place-specific and specialized by education and enabled by technology, constantly exploiting its specialization for the innovation activities and economic benefits. This research paper might be a valuable source of information for studying the development of creativity, society in general and creative economy. The further research and practical application could be used to develop indictors of creative society and apply them to study different regions with different specializations.
\end{abstract}

Keywords: creative economy, creative society, information society, knowledge society, regional specialization.

\section{Introduction}

The term "creative society" can be used in the two following ways: in the first case it labels the society as being creative or interchangeably inventive. Creativity is just the one of the possible features, likely the most important one, which can be attributed to the contemporary society. In the second case the creative society should be understood as a phenomenon. It is a name of the contemporary society, not limited only to one attribute as being creative, but emphasizing the creativity as state of the society, affecting all other attributes. 
At the moment there is no widespread, solid and universal description of the creative society, thought it seems that there is an agreement that the contemporary society can be described not only as creative, but as based on the creativity and exposing new features or a new combination of traditional features. The better picture of this postmodern form of the society, which is expressing itself by creation and consummation of "constantly something new", could be constructed of clear and rather well established ideas and concepts.

By no doubt it is important to understand the possible evolution directions of the society and already existing implications from technology and globalisation. One could argue that creative society is yet another label to the information or knowledge society, but there is evidence that some fundamental changes are happening. As the term creative society is being used already for some time, the efforts to come up with the explanation and definition are very scarce. The main goal of this research paper is to analyse the phenomenon of creative society. The objectives are (1) to analyse and review existing understanding, (2) to propose the features, distinguishing it from the information society and knowledge society and (3) to discuss the relation of creative society with creative economy and regional specialization - the main application fields of the phenomenon. Research is based on the broad analysis of the relevant literature from various fields of science and different schools of thought. Based on the review, the features are synthesized and provided together with the effects.

It should be mentioned, that recently the topic of creative society has been increasingly discussed among Lithuanian scholars as Jovilè Barevičiūtè (2014), Tomas Kačerauskas (2014a, 2014b), Valdas Pruskus (2015) and Nerijus Stasiulis (2015).

\section{Features of the creative society}

Creative society is an expansion or evolution of information and knowledge society. As knowledge society does not contradict the information society and in opposite, it complements and deepens some of the common attributes, creative society is not a contradiction to the both mentioned above. It should be understood as a continuity of development. Two main dimensions, illustrating the change that is taking place are widespread of technology and its application for creativity and specialization (Fig. 1).

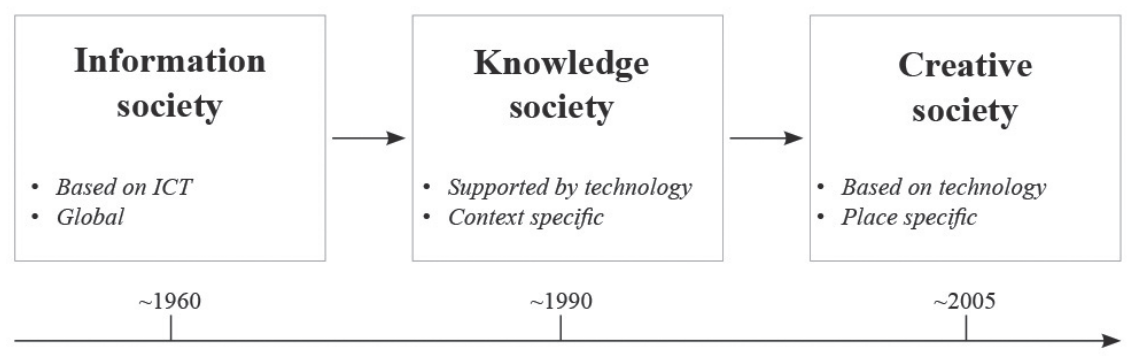

Technology and specialization

Fig. 1. Progression of information society Source: created by author 
The widespread of technology dimension describes the constant application of the technologies in the everyway of the society. As for information society the technology or mainly information and communication technologies were the main enabler, the knowledge society was applying technologies in a more mature way. Technologies began to change not only the way of communication and organization of work, but the productivity became rather dependent of the technologies. The culture of the society was affected as well. The next step of the widespread technological application is penetration of it to the every aspect of life, with the dependence much broader than just the work or communication. Another dimension hence specialization, describes the focus of the term attributed to the society. Information society is a global non-specialized phenomenon, with no physical boundaries, just the ones impelled by the usage of information and communication technologies. Specialization of the knowledge society very much depends on the context or in other words on the context where the knowledge is applied. Creative society is the most sensitive place and place specific phenomenon of all three discussed, as there is no equally creative communities or regions with equal conditions for creativity. In order to understand the phenomenon of creative society an analysis of the relevant literature from different scholar has been carried out. The main findings are provided below.

First of all - creative society is a postmodern society, with the essential changes in the production and especially in leisure and entertainment, it could be named a post-creative society (Kačerauskas 2014a, 2014b). Additionally creative society can be seen as prosperity of the society based on innovation, where everyone's creative potential is exploited. The success is based on the ability to produce more value, but not more products. Technology becomes the distinguishing feature of the society (Webster 2009). Creativity is revealed not only in product and process technology, but also in cultural and artistic pursuits (The World Bank 2013). Technology, science and art become nearly of the same importance. Moreover - "art is what helps make a society from an economy" (Australian Government 2013). Creative society is based on innovation, competitiveness and mostly important - exclusivity. According to a future study published by Organisation for Economic Co-Operation and Development (Stevens et al. 2000), there is a good chance (from the year 2000 perspective) that societal transformations will bring forward "uniqueness and creativity of a knowledge economy and society" in an integrated world. Through uniqueness or exclusivity as way of being special and different from others, the creative society is based on specialization. Creative society involves all its potential innovators in the technological, service and social innovation process, including every citizen (European Commission C 2013) and "the roots of creative society are in the basic education" (Morris 2006). Wayne Morris believes that creative students lead richer lives and make a great contribution to the society in the future. Louis Galambos in his book Creative Society (2012) argues that modern American society is based on education of professionals, who over the years “didn't entirely produce new ideas but instead negotiated the compromises that enabled the society to move on to the next big problem. [...] The professionals came to play a central role in all of the country's crisis". As Fredrik Härén (2010) describes it, the creative society is "the fast growing group of well educated 
people who can wrestle with creative problems". The present creative class of creative society is based on the professionalism delivered by education.

From the economical perspective - models of economy signify the status of the society. For example the knowledge economy is based on the knowledge society and knowledge management. The same logic represents creative society as the foundation of the creative economy and creative (and cultural) industries. The bond is bidirectional, because movement towards more creative economy and more creative society requires a better segregation of Creative and Cultural Industries from other industries (Hogeschool voor de Kunsten Utrecht 2010). Creative society is transforming the place where it exists, representing the element of "embeddedness" or connectedness with the geographical place of its location. "The new economy and its "seminomadic workforce' will require 'new places to gather, work, live, and interact"' (Coonerty, Neuner 2013). Moreover, the governments around the world are constantly competing to create a better environment in order to attract the talented workers - the workers of the creative economy (Yigitcanlar 2009). The economical growth is frequently seen as based on the creativity, on the new recipes and new combination of local capital and via innovation centers (Breznitz, Noonan 2014).

Another pillar of the creative society is the concept of the creative workers. Back in 2002, Richard Florida introduced a concept of creative class - a group of professionals in the fields from science to art with the aim to create new ideas, technologies and content that would have a high input to the economical, social and cultural dynamics of the region or the whole country. In this theory creative class is embedded in the city as the main interconnected work and leisure space (Florida 2002). It does not matter from which sector the workers are - it can be finance, literature, computer programming, etc. - the creativity in their functions is what matters. The creative class is based on the individualism, meritocracy, diversity and openness (Levickaite, Reimeris 2011) or in other terms - technology, talent and tolerance also known as 3T model (Florida 2005). As Tom Peters (2003) sees it - the creative society is when each person moves from project to project and from one gig to another what represents the fast pace and diversity of constant innovation. Brad Feld (2012) uses the term "startup communities" to describe the different innovation capacities of the communities. Start-up communities are the energy, activity and innovation that occur in small geographic regions, led by entrepreneurs and involving anyone who wants to participate. Creativity is what makes people, firms and regions unique (Sleuwaegen, Boiardi 2014). One of the main features of the creative society is that it is not a hierarchical, but a multi-stakeholder holistic society with many centers of influence that can be located at the bottom or at the top of the hierarchical pyramid.

Technology is the biggest enabler of creative society. As Ben Schiller (2014) argues the "making" is going mainstream. People who would never consider themselves to be traditionally "creative" are starting to develop various skills like coding, design, art making, etc. and, being the part of creative society, they are coming up with useful and practical applications of that. Creative society is represented by individual workers, with a unique opportunity to align economic and human development in a new way, creating "the possibility of making a living while also making a life" (Coonerty, Neuner 2013). 
The review of the literature and concepts allows synthesizing a list of features that are applicable to the concept of the creative society, as many scholars described it. The most important and distinguishing (in a sense of information or knowledge society) features of the creative society are provided in a Table 1.

Table 1. Features of the creative society

\begin{tabular}{|c|c|}
\hline Features & Description \\
\hline Non-hierarchical & $\begin{array}{l}\text { The structure of the society is based on the networks of multiple } \\
\text { stakeholders in various levels which makes the creative society non } \\
\text { hierarchical and inclusive. The levels or certain type of hierarchy } \\
\text { still exists, but the influence of stakeholder is created not by the } \\
\text { level it represents. }\end{array}$ \\
\hline $\begin{array}{l}\text { Individual approach to the } \\
\text { creation }\end{array}$ & $\begin{array}{l}\text { The smallest creative unit of this society in the economical per- } \\
\text { spective is every citizen that can be active and self-substantial } \\
\text { influencer for the other members. The forms of possible creative } \\
\text { activity are very different and exploited according to individual } \\
\text { knowledge, environment and skills. }\end{array}$ \\
\hline Exclusivity & $\begin{array}{l}\text { Creative society is empowered by exclusivity and constant strive } \\
\text { for creating and consuming something new, whether it is a product } \\
\text { or service, concept or idea. The creation, as well as consummation } \\
\text { of something new and different is a way for exclusivity, distin- } \\
\text { guishing individual members and larger groups of society from } \\
\text { others. }\end{array}$ \\
\hline $\begin{array}{l}\text { Foundation of the creative } \\
\text { economy }\end{array}$ & $\begin{array}{l}\text { Similarly as knowledge economy is based on knowledge society, } \\
\text { the foundation of economy of creative products and services lies in } \\
\text { the human capital and social capital, which together stands for the } \\
\text { creative society. }\end{array}$ \\
\hline $\begin{array}{l}\text { Embedded to the place } \\
\text { where it exists }\end{array}$ & $\begin{array}{l}\text { Creative society is connected and specialized according to the place } \\
\text { where it is situated, reflecting political, social, economical, tech- } \\
\text { nological and etc. features of the location. Creative society is exer- } \\
\text { cising and amplifying the regional uniqueness or specialization. }\end{array}$ \\
\hline Roots in the education & $\begin{array}{l}\text { Education should be understood as the main enabler for the creativ- } \\
\text { ity of the society, providing not only the required knowledge, but } \\
\text { also skills and networks. The differences in mass education sys- } \\
\text { tems and the availability of life long learning makes the societies } \\
\text { diverse and specialized. }\end{array}$ \\
\hline Based on technology & $\begin{array}{l}\text { Technology brings new ways of communication, new possibilities } \\
\text { for activity with economical benefits, social engagement, creation } \\
\text { and dissemination of creative content. Technology shapes the soci- } \\
\text { ety from the emergence of information society and is the integral } \\
\text { part of it. Creative society and its expression is based on the tech- } \\
\text { nology, but relation here is mutual - the progress of technology is } \\
\text { very much dependent on the creative society as it finds new ways } \\
\text { and meanings for the technological advancement. }\end{array}$ \\
\hline
\end{tabular}

Source: created by author. 
In summary, the creative society is the foundation of the creative economy embedded to the place where it exists. It is organized in non-hierarchical form and opts for the exclusivity, with individual approach to the creation and specific roots in the education. By its nature the creative society is very place-specific and specialized by education and enabled by technology, constantly exploiting its specialization for the innovation activities and economic benefits.

\section{Relation to creative economy}

Li Wuwei (2011) argues another view on the creative society and its connection to the creative economy and creative industries. According to Wuwei (2011) the creative industries represent the input of art and culture to the economy, creative economy represents the creative spillovers in other sectors (not in the creative industries sectors) and creative society represents much wider effects as creative communities in creative cities, various interactions between creative groups and geographical areas. The differences and evolution are provided in a Table 2 .

In this case the creative society is more like a social representative of the industry and economy. The creative society is the main actor in the creation of the favourable environment, the sustainability for the creative economy and acts as the civil society

Table 2. Evolution of creative industries

\begin{tabular}{|l|l|l|l|}
\hline \multicolumn{1}{|c|}{ Phase } & \multicolumn{1}{c|}{ Creative industries } & \multicolumn{1}{c|}{ Creative economy } & \multicolumn{1}{c|}{ Creative society } \\
\hline Factor & Culture, art, creativity & $\begin{array}{l}\text { Intellectual property; } \\
\text { Symbolic value }\end{array}$ & $\begin{array}{l}\text { Citizen's right; } \\
\text { Consumer's recognition }\end{array}$ \\
\hline Form & $\begin{array}{l}\text { Cultural industry; } \\
\text { Creative clusters }\end{array}$ & $\begin{array}{l}\text { Creativity as intermediate } \\
\text { input factors; } \\
\text { Build up on creative indus- } \\
\text { trial chain }\end{array}$ & $\begin{array}{l}\text { Creative city; } \\
\text { Creative class; } \\
\text { Creative community }\end{array}$ \\
\hline Feature & Creative output & Creative input & Creative spillover \\
\hline Industry & Key industries & Convergent industries & $\begin{array}{l}\text { Branding symbol of } \\
\text { industries }\end{array}$ \\
\hline Target & $\begin{array}{l}\text { To promote creative } \\
\text { output }\end{array}$ & $\begin{array}{l}\text { To foster innovations in } \\
\text { broader domains }\end{array}$ & $\begin{array}{l}\text { To build creative } \\
\text { communities }\end{array}$ \\
\hline $\begin{array}{l}\text { Policy } \\
\text { implication }\end{array}$ & $\begin{array}{l}\text { New wealde industry } \\
\text { vereation }\end{array}$ & $\begin{array}{l}\text { To transform the economic } \\
\text { development model; } \\
\text { Creative industries as } \\
\text { a part of a system of } \\
\text { innovation }\end{array}$ & $\begin{array}{l}\text { Consumer as input factors; } \\
\text { Economic and social co- } \\
\text { developed structure with } \\
\text { people at the center; } \\
\text { To build up enabling creat- } \\
\text { ive environment }\end{array}$ \\
\hline Policy focus & $\begin{array}{l}\text { To nurture the source } \\
\text { of creativity }\end{array}$ & $\begin{array}{l}\text { To build up soft creative } \\
\text { environment for creative } \\
\text { transformation and input }\end{array}$ & $\begin{array}{l}\text { Reconfiguration of con- } \\
\text { sumption, educational } \\
\text { system and institutional } \\
\text { system }\end{array}$ \\
\hline
\end{tabular}

Source: adapted from Wuwei 2011. 
part of the quadruple helix model (Colapinto, Porlezza 2012). The specialization of the creative society can be described using the concept of creative milieu. In some sources of literature (Törnqist 1983) the creative milieu is described as a social aspect of creativity, which is an important fact for the economical regional growth and competitiveness. Creative milieu consists of three characteristics:

1. A large resource of information and ease if its distribution across the area;

2. A large amount of knowledge amassed over the time;

3. Large resources of competence in the particular activities.

Creative milieu is the degree to which people feel like a part of the region and is the factor for regional innovativeness. This concept is directly connected with the concept of Smart specialization, what has the organizational role of creative milieu. In other words - Smart specialization is the form that represents the creative society, based on the regional specifics.

Frank Webster (2009) puts forward the idea that the way we consume information is a matter of self-expression. "Contemporary culture is manifestly more heavily information laden that any of its predecessors". Again, it does not contradict information society phenomenon, but rather expands it. Knowledge has increasingly more complex nature what makes cooperation and networking with external sources an obligatory competence for obtaining the complimentary pieces of knowledge and avoiding the lock-in the historical specializations (Camagni, Capello 2013). This new form of society will constantly negotiate the state of being individual and collective at the same time. The openness of the society can be illustrated by the following statement: "Communication technologies, freedom to move and all different aspects of globalization contribute to an effect which can be considered a 'solve a problem' competing with the standard 'let's solve a problem together as we know each other"' (Meissner et al. 2013).

The concept of community, which relies on the common interests, differs from the concept of organization that is more spontaneous and natural (Román et al. 2013). One of the future research questions can investigate the possibility for regional community act as an economically specialized and skilled company. Such intangible aspects as creativity, culture and taste represents the development of specialized skills and specialized human capital in the local communities (Camagni, Capello 2013). The immersion into the postmodern state of the society will without any doubts bring new forms of living, working, leisure and integration of it all. "We exist in a media-saturated environment that means that life is quintessentially about the symbolization. $<\ldots>$ and is characterized by constant change" (Webster 2009). The management aspect of the creative society is contextualized in the holistic and sustainable model, integrating social, political, technological and cultural dimensions (Augustinaitis, Petrauskas 2011).

It is evident, that creative economy is very dependant on the creative society, as it affects such important spheres as environment of creativity, innovativeness and regional specialization. Creative society is neither individual nor collective, or both at the same time with some attributes similar to the business entity (a company). The state of the economical openness and attractiveness might be dependant of the creative society as well. 


\section{Conclusions}

In summary, creative society is an extension to information society and knowledge society, but with the different set of main features. Creative society is foundation of the creative economy embedded to the place where it exists. It is organized in non-hierarchical form and opts for the exclusivity, with individual approach to the creation and specific roots in the education. By its nature the creative society is very place-specific and specialized by education and enabled by technology, constantly exploiting its specialization for the innovation activities and economic benefits. Smart specialization is the form that represents the creative society, based on the regional specifics.

Creative society represents much wider effects as creative communities in creative cities, various interactions between creative groups and geographical areas new forms of living, working, leisure and integration of it all. Creative society represents essential changes in the production and especially in leisure and entertainment. Relation with creative economy can be expressed by a concept of creative milieu which describes to what degree people feel like a part of the region.

This research paper might be a valuable source of information for studying the development of creativity, society in general and creative economy. The further research and practical application could be used to develop indictors of the creative society and apply them to studying different regions with different specializations. As the state of the economical openness and attractiveness might be dependent on the creative society as well, it might be very important to fully understand the creative society, find appropriate indicators to measure it and find ways to develop the new phenomenon.

\section{References}

Augustinaitis, A.; Petrauskas, R. 2011. Civil Society Technologies: Communication Approach, in International Conference of Social Technologies '11: ICT for Social Transformations, 17-18 November 2011, Faculty of Social Informatics, Mykolas Romeris University, Vilnius, Lithuania, $54-65$.

Australian Government. 2013. Creative Australia: National Cultural Policy [online], [cited 20 November 2013]. Available from Internet: http://creativeaustralia.arts.gov.au/assets/CreativeAustralia-PDF-20130417.pdf

Barevičiūtė, J. 2014. Pagrindiniai kūrybiškumo ir kūrybingumo aspektai šiuolaikiniuose humanitariniuose bei socialiniuose moksluose, Filosofija. Sociologija 25(1): 19-28.

Breznitz, Sh. M.; Noonan, D. S. 2014. Arts Districts, Universities, and the Rise of Digital Media, The Journal of Technology Transfer 39: 594-615. http://dx.doi.org/10.1007/s10961-013-9315-x

Camagni, R.; Capello, R. 2013. Regional Innovation Patterns and the EU Regional Policy Reform: Towards Smart Innovation Policies, Growth and Change: A Journal of Urban and Regional Policy 44(2): 355-389.

Colapinto, C.; Porlezza, C. 2012. Innovation in Creative Industries: From the Quadruple Helix Model to the Systems Theory, Journal of the Knowledge Economy 3(4): 343-353. http://dx.doi. org/10.1007/s13132-011-0051-x

Coonerty, R.; Neuner, J. 2013. The Rise of the Naked Economy: How to Benefit from the Changing Workplace. New York: Saint Martin's Press. 
European Commission C. 2013. Work Programme 2013. Capacities: Science in Society. Part 5 [online], [cited 16 December 2014]. Available from Internet: http://ec.europa.eu/research/ participants/data/ref/fp7/134006/s-wp-201301_en.pdf

Feld, B. 2012. Startup Communities: Building an Entrepreneurial Ecosystem in Your City. New Jersey: Wiley.

Florida, R. 2005. Cities and the Creative Class. New York: Routledge.

Florida, R. 2002. The Rise of the Creative Class. New York: Basic Books.

Galambos, L. 2012. The Creative Society - and the Price Americans Paid for It. New York: Cambridge University Press.

Härén, F. 2010. The Developing World: How an Explosion of Creativity from Developing Countries Is Changing the World - And Why the Developed World Should Start Paying Attention. Singapore: Interesting Books.

Hogeschool voor de Kunsten Utrecht. 2010. The Entrepreneurial Dimension of the Cultural and Creative Industries. Utrecht: Utrecht University Press.

Kačerauskas, T. 2014a. Kürybos visuomenè. Vilnius: Technika. http://x.doi.org/10.3846/2265-M

Kačerauskas, T. 2014b. Kūrybos visuomenè: tyrimo metodai ir problemos, Logos-Vilnius 80: $6-15$.

Levickaitè, R.; Reimeris, R. 2011. Kūrybos ekonomikos penkiakampis, Santalka: filosofija, komunikacija 19(1): 83-91.

Meissner, D.; Roud, V.; Cervantes, M. 2013. Innovation Policy or Policy for Innovation? - In Search of the Optimal Solution for Policy Approach and Organisation, in Meissner, D.; Gokhberg, L.; Sokolov, A. (Eds.). Science, Technology and Innovation Policy for the Future: Potentials and Limits of Foresight Studies. Heidelberg: Springer, 247-255.

Morris, W. 2006. Creativity - It's Place in Education [online], [cited 28 November 2014]. Available from Internet: http://www.future-edge.co.nz/Files/Creativity\%20in\%20Education.pdf

Peters, T. 2003. Re-Imagine! Business Excellence in a Disruptive Age. London: DK Publishing.

Pruskus, V. 2015. Kūrybingumo panaudojimo gerinant aplinkos kokybę etiniai ir socialiniai kultūriniai aspektai, Filosofija. Sociologija 26(3): 201-209.

Román, J. Á.; Rodríguez, S.; Corchado, J. M. 2013. Distributed and Specialized Agent Communities, in Bajo Pérez, J.; Corchado Rodríguez, J. M.; Fähndrich, J.; Mathieu, Ph.; Campbell, A.; Suárez-Figuaeroa, M. C.; Ortega, A.; Adam, E.; Navarro, E.; Hermoso, R.; Moreno, M. N. (Eds.). Advances in Intelligent Systems and Computing 221: Trends in Practical Applications of Agents and Multiagent Systems. 11th International Conference of Agents and Multi-Agent Systems. Heidelberg: Springer, 33-40.

Schiller, B. 2014. 8 Unexpected Ways Technology will Change the World by 2020 [online], [cited 20 November 2014]. Available from Internet: http://www.fastcoexist. com/3024455/8-ways-technology-will-change-everything-by-2020

Sleuwaegen, L.; Boiardi, P. 2014. Creativity and Regional Innovation: Evidence from EU Regions, Research Policy 43(9): 1508-1522. http://dx.doi.org/10.1016/j.respol.2014.03.014

Stasiulis, N. 2015. Kūrybos visuomenè Lietuvoje. Kūrybos visuomenès vizija ir gairès, LogosVilnius 83: 6-12.

Stevens, B.; Miller, R.; Michalski, W. 2000. Social Diversity and the Creative Society of the 21st Century, in The Creative Society of the 21st Century. Paris: Organisation for Economic CoOperation and Development, 7-24. 
The World Bank: Development Research Center of the State Council, the People's Republic of China. 2013. China 2030: Building a Modern, Harmonious, and Creative Society [online], [cited 28 November 2014]. Available from Internet: http://documents.worldbank.org/curated/ en/2013/03/17494829/china-2030-building-modern-harmonious-creative-society

Törnqist, G. 1983. Creativity and the Renewal of Regional Life, in Buttimer, A. (Ed.). Creativity and Context: Lund Studies in Geography 50. Series B.: Human Geography, 91-112.

Webster, F. 2009. Information Society, in Bates, M. J. (Ed. in Chief). Encyclopedia of Library and Information Sciences, 1338-1357.

Wuwei, L. 2011. How Creativity Is Changing China. London: Bloomsbury Academic.

Yigitcanlar, T. 2009. Spatial Restructuring of Cities in the Age of Knowledge Economy: Insights from Australian Cities, in Proceedings of the 2nd Knowledge Cities Summit. 5-6 November 2009, Shenzhen, China, 1-14.

\title{
KŪRYBOS VISUOMENĖS TEORINĖS SAVYBĖS
}

\section{Ramojus REIMERIS}

\begin{abstract}
Santrauka
Šio straipsnio tikslas - dvejopas. Pirma, siekiama apibūdinti ir išanalizuoti kūrybos visuomenès reiškinị ir jo savybes, kurios jị atskiria nuo informacinės visuomenès ir žinių visuomenès. Antra, siekiama atskleisti kūrybos visuomenès sąryšius su kūrybos ekonomika ir regionine specializacija. Tyrimas paremtas literatūros analize, kuri atskleidžia, kad kūrybos visuomenè yra informacinès ir žinių visuomenès tąsa, tačiau turinti kitokias pagrindines savybes. Kūrybos visuomenė yra kūrybos ekonomikos pagrindas ir įsitvirtinusi toje vietoje, kurioje egzistuoja. Kūrybos visuomenès valdymo struktūra yra nehierarchinė; kūrybos visuomenė siekia išskirtinumo, joje vyrauja individualus požiūris ił kūrybą, o specifinès šaknys glūdi išsilavinime. Savo pobūdžiu kūrybos visuomenè yra labai specifinè konkrečios vietos atžvilgiu, specializuota pagal išsilavinimą ir turinti plačias technologines galimybes, išnaudojanti savo specializaciją inovatyvioms veikloms ir ekonominei naudai. Šis straipsnis gali būti naudingas informacijos šaltinis studijuojant kūrybingumo pletrą, visuomenę ir kūrybos ekonomiką. Tolesni tyrimai ir praktinis pritaikymas gali būti panaudoti plètojant kūrybos visuomenès rodiklius, o vẻliau juos taikant įvairių specializacijų regionams tirti.
\end{abstract}

Reikšminiai žodžiai: kūrybos ekonomika, kūrybos visuomenè, informacinè visuomenè, žinių visuomenè, regioninè specializacija. 